\title{
三
}
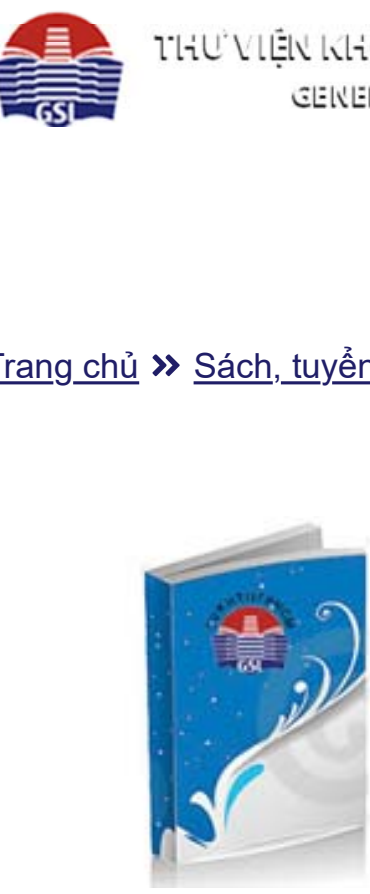

$$
\text { Sách, tuyển tập }
$$

Nguyên lý tài chính - toán của thị trường

Tác giả : Vương Quân Hoàng

Nhà xuất bản : Chính trị Quốc gia

Năm xuất bản : 2000

Nơi xuất bản : Hà Nội

Mô tả vật lý : 304 tr. : biểu đồ ; 22 cm

Số phân loại : 332.632

Chủ đề : 1. Thị trường chứng khoán -- Mô hình toán học. 2. Thị trườn

\section{Chia sẻ}

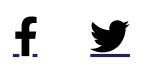

\section{Thông tin xếp giá}

Thư viện: Thư viện KHTH

Kho lưu trữ: Kho 8

KH sách/vị trí: VV 4910/A

Trạng thái: Sẵn sàng phục vụ (Đọc/Mượn)

Đăng ký mượn: Mượn 
Sách tiânựẹuanThư viện KHTH

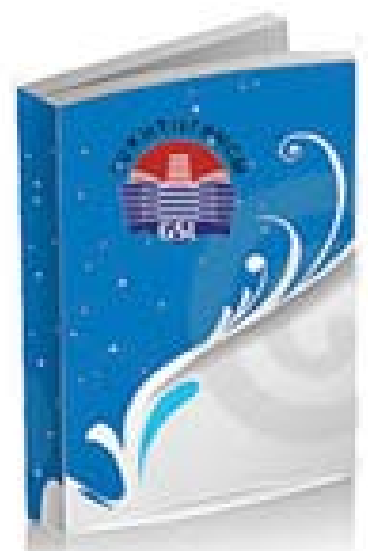

Hướng dẫn soạn thảo văn bản giao dịch trê...

Tác giả : Nguyễn Minh Đức, Lê Thành Kính, Phan Thành Đạt

Nhà xuất bản : Thống kê

Năm xuất bản : 2000

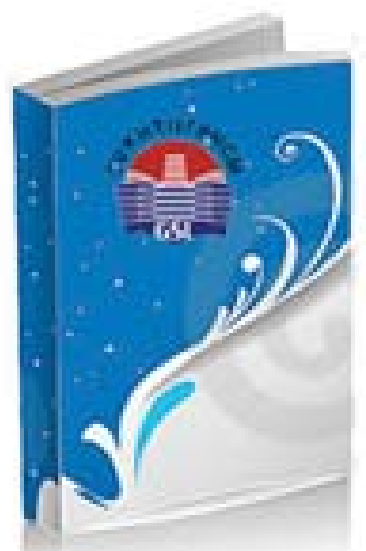

Phân tích kỹ thuật thi trường tài chính : cẩ...

Tác giả : John J. Murphy ; người dịch, Lê Đạt Chí, Tường Vy ; hiệu đính, Phan Thị Bích Nguyệt

Nhà xuất bản : Nxb. Tổng hợp T.P. Hồ Chí Minh

Năm xuất bản : 2011

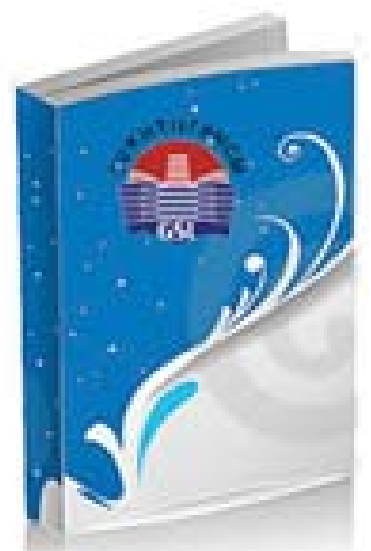

Preferreds : Wall Street's best-kept...

Tác giả : by Kenneth $\mathrm{G}$. Winans.

Nhà xuất bản : KGW Pub. Năm xuất bản : 2007

\section{Thư Viện Khoa Học Tổng Hợp Tp.HCM @ 2020. Hướngdẫn}

Địa chỉ : 69 Lý Tự Trọng, Phường Bến Thành, Quận 1, Tp.Hồ Chí Minh

Điện thoại : +84 (8) 38225055 | Fax : +84 (8) 38299318

Email : thuvientphcm@thuvientphcm.gov.vn 